\title{
Spatial and temporal trends of heavy metal accumulation in mosses in Estonia
}

\author{
H. Kösta \& S. Liiv \\ Department of Environmental Education, \\ Tallinn Botanic Garden, Estonia
}

\begin{abstract}
The main sources of air pollution with heavy metals in Estonia are the country's oil shale fired power stations, the chemical and the building materials industry and road traffic. The principal power stations and most of heavy industry are concentrated in the north-eastern part of the country. The relative deposition of $\mathrm{Cd}, \mathrm{Cr}, \mathrm{Cu}, \mathrm{Fe}, \mathrm{Ni}, \mathrm{Pb}, \mathrm{V}$ and $\mathrm{Zn}$ in Estonia has been monitored since 1989 by the method of bioindication, using the mosses Pleurozium schreberi or Hylocomium splendens as indicator species. The selection of sampling sites and the collection of moss samples is carried out in accordance with the requirements of the International Cooperative Programme on Effects of Air Pollution on Natural Vegetation and Crops. In 1989, heavy metals concentrations in mosses were the highest in samples from North-East Estonia. By 1995, the surroundings of Tallinn, the capital city of Estonia, had become the second most polluted area in Estonia, probably due to increased traffic density and the related increase in air pollution. In 2005-2008, the changes of the concentrations of most heavy metals in mosses remained within or close to local variability in all studied regions. During 1989-2006, the decrease of heavy metals concentrations in Estonian moss samples has been in correlation with the drop in power production as well as with the decrease of emission of pollutants due to the implementation of environmentally friendlier technologies. Due to the introduction of unleaded petrol in Estonia, the concentration of lead in moss samples has decreased by up to $60 \%$ during $1989-2008$.
\end{abstract}

Keywords: atmospheric pollution, emission sources, heavy metals, mosses as biomonitors. 


\section{Introduction}

The widespread carpet-forming mosses Pleurozium schreberi and Hylocomium splendens possess excellent properties for monitoring the atmospheric deposition of heavy metals. There are a variety of natural and anthropogenic sources of heavy metals in the environment.

The main natural sources of heavy metals are volcanic activity, forest fires, biogenic sources and the erosion of crusty materials (Sucharova and Suchara [1]; Callender [2]). To date the most important sectors of anthropogenic emission of various common metals are the metals industry (emissions of $\mathrm{Al}, \mathrm{As}, \mathrm{Cr}, \mathrm{Cu}, \mathrm{Fe}$, $\mathrm{Zn}$ ), other manufacturing and construction industries (emissions of $\mathrm{As}, \mathrm{Cd}, \mathrm{Cr}$, $\mathrm{Hg}, \mathrm{Ni}, \mathrm{Pb}$ ), electricity and heat production (emissions of $\mathrm{As}, \mathrm{Cd}, \mathrm{Hg}, \mathrm{Ni}$ ) and road transport (emissions of $\mathrm{Cu}, \mathrm{Sb}, \mathrm{Pb}, \mathrm{V}, \mathrm{Zn}$ ) (Fukuzaki et al. [3]; Ikeda et al. [4]; Sternbeck et al. [5]; Adachi and Tainosho [6]; Harmens et al. [7]).

In Estonia, the main sources of heavy metal emissions are thermal power stations (Eesti Power Plant and Balti Power Plant, whose combined maximum generation capacity exceeds $3 \mathrm{GW}$ ), the cement production plant operated by the public limited company Kunda Nordic Tsement AS and the chemical industry (the Nitrofert fertilizer plant, the oil shale processing plant of the Viru Keemia Group) - all located in North-East Estonia (NE Estonia). In addition to these, the emissions are produced also by various local industries, heating plants and traffic around major towns and on major roads (Liiv and Kaasik [8]).

A specific feature in relation to Estonia is its possession of considerable oil shale deposits. Oil shale has been mined and used in Estonia for more than 80 years - by March 2006, the country had extracted one billion tonnes of oil shale. Since the 1960s, Estonia has been the largest oil shale producer and consumer in the world. In the 1980s about two thirds of the world's oil shale output came from Estonia (Punning and Raukas [9]).

Thermal combustion of oil shale in power plants leads to increasing amounts of heavy metal emissions (some of which are radioactive) which are partly deposited in the ash fields and partly emitted into the atmosphere (Punning and Raukas [9]). In 2002, about $97 \%$ of air pollution, $86 \%$ of total waste and $23 \%$ of water pollution in Estonia came from the power industry, which uses oil shale as the main input for production process (Raukas [10]).

Even in the absence of visible pollution, trace amounts of heavy metals may accumulate in the environment and, over long periods of time, pose a major environmental and human health hazard (Walkenhorst et al. [11]).

In living organisms, heavy metals mostly accumulate in bone cells, kidneys and liver, where they may cause a variety of chronic diseases, toxemia and even cancer. Food chain contamination is the most important pathway for the entry of these chemical elements into the human body (Ferner [12]; Ma et al. [13]).

The use of widespread native terrestrial mosses as biomonitors is a wellrecognized technique in studies of atmospheric contamination (Rühling and Tyler [14]; Sucharova and Suchara [1]; Holy et al. [15]). Mosses are easy to handle, they lack the cuticle, vascular and root systems and are capable of absorbing and fixing metallic pollutants from the atmosphere in their tissues over 
long periods of time (Brown [16]; Brown and Brumelis [17]; Tyler [18]; Sawidis et al. [19]; Thöni et al. [20]; Markert et al. [21]; Fernandez et al. [22]).

Monitoring the concentrations of metals in mosses provides a surrogate, timeintegrated measure of the deposition of these elements from the atmosphere to terrestrial biosystems. The fact that moss biomonitoring studies are comparatively cheap permits a higher sampling density to be achieved than would be possible with conventional deposition measurements (Holy et al. [15]; Harmens et al. [7]).

The relative deposition of $\mathrm{Cd}, \mathrm{Cr}, \mathrm{Cu}, \mathrm{Fe}, \mathrm{Ni}, \mathrm{Pb}, \mathrm{V}$ and $\mathrm{Zn}$ has been monitored in Estonia by recording their concentrations in the epigeic mosses Pleurozium schreberi and/or Hylocomium splendens since 1989, when Estonia joined the North European air pollution monitoring programme Atmospheric Heavy Metal Deposition in Northern Europe (Rühling et al. [23]; Mäkinen [24]).

\section{Methods}

Every fifth year $(1989 / 1990 ; 1995 ; 2000 / 2001 ; 2005 / 2006)$ a national moss study has been carried out in Estonia. The study scheduled for 2010/2011 is currently in progress - moss samples have already been collected from 100 sampling sites organised as a grid whose density is approximately $30 \mathrm{~km}$.

In areas where pollution loads are high or critically high, a denser sampling grid has been used (Liiv and Kaasik [25]). Thus, in 1992, 1997, 2002, and 2007 moss samples were collected around two large oil shale fired thermal power stations and a cement factory in the north-eastern part of the country (NE Estonia). In 2003 and 2008, moss samples were collected along the transects originating from Tallinn (the capital city of Estonia with 403,000 inhabitants) within a $35 \mathrm{~km}$ radius, fig. 1 .

Sampling sites were selected with a view to meeting the requirements of the standardized methodology elaborated by the European bio-monitoring project (Rühling et al. [23]).

The sampling of mosses was adapted to the methods of European moss study (Rühling et al. [26]; Atmospheric Heavy Metal Deposition in Northern Europe [27]). There was no significant interspecies difference in the uptake of $\mathrm{Cd}, \mathrm{Cr}$, $\mathrm{Cu}, \mathrm{Fe}, \mathrm{Ni}, \mathrm{Pb}, \mathrm{V}$ and $\mathrm{Zn}$ by $P$. schreberi and H. splendens in Estonia (Liiv and Kaasik [25]). The concentrations of these elements were determined at the Finnish Forest Research Institute (Metla) using inductively coupled plasma emission spectrometry (ICP-ES).

In order to determine which differences and trends in concentrations are significant, a local variability criterion was used. In 1996, 25 samples were collected from each of the three sampling sites (one in NE Estonia - the seat of the country's oil shale deposits and the region which the development of these deposits affects the most, one in South-East Estonia and one on the Hiiumaa island off the west coast of Estonia). The samples were analysed separately at the laboratory of the Institute of Ecology of the University of Lund (Sweden) by means of the ICP-ES method. The local variability for each of the sites was calculated by computing the standard deviation of the respective dataset, 


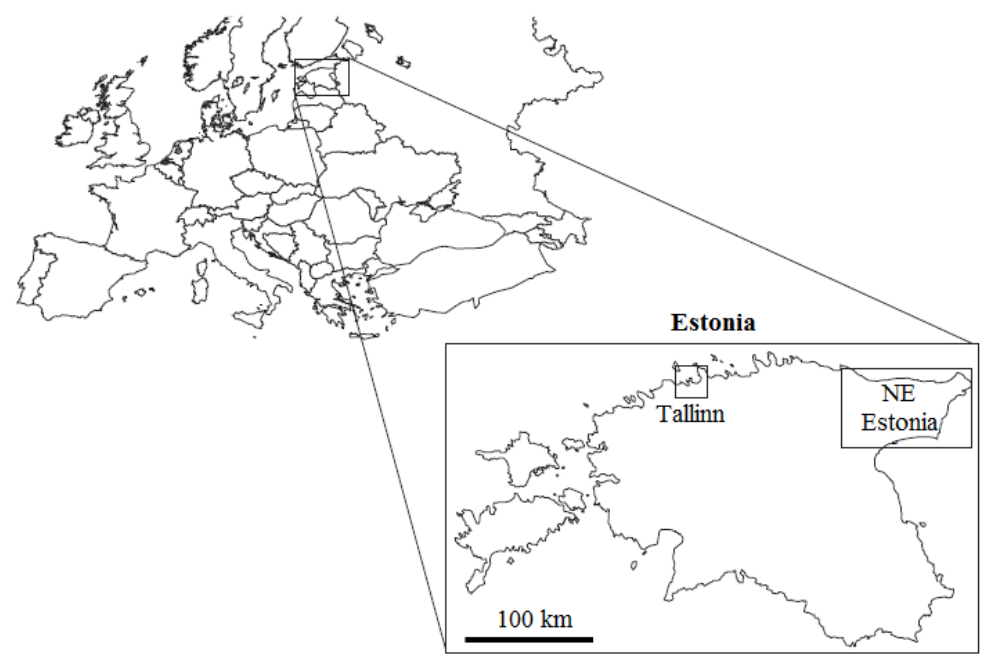

Figure 1: Locations of sampling areas with a higher density grid: NE Estonia and the surroundings of Tallinn, in 1989-2008 (Liiv and Kaasik [8]).

multiplying it by two and adding the standard error of the analytical method used. The local variability values used in this article are the largest of the corresponding figures for the three sampling sites. These values are: $\mathrm{Cd}-$ $0.054 \mu \mathrm{g} / \mathrm{g}, \mathrm{Cr}-0.84 \mu \mathrm{g} / \mathrm{g}, \mathrm{Cu}-0.89 \mu \mathrm{g} / \mathrm{g}, \mathrm{Fe}-235 \mu \mathrm{g} / \mathrm{g}, \mathrm{Ni}-0.59 \mu \mathrm{g} / \mathrm{g}, \mathrm{Pb}-$ $3.0 \mu \mathrm{g} / \mathrm{g}, \mathrm{V}-1.11 \mu \mathrm{g} / \mathrm{g}, \mathrm{Zn}-6.95 \mu \mathrm{g} / \mathrm{g}$ (Liiv and Kaasik [8]).

In order to characterize the results of the moss analyses performed, a set of boxplot charts - one for each of the heavy metals whose deposition was measured in the study - was created, showing minimum, maximum and median values along with the first and the third quartile of the concentrations.

\section{Results}

Cd - Since 1989, the concentrations of Cd in Estonia's mosses have decreased considerably throughout the country. In 1989-2004, the median values of such concentrations in NE Estonia dropped by up to 48\%. In 2005-2008, the median values of $\mathrm{Cd}$ concentrations in moss samples were almost identical in all three sampling regions: the entire Estonia (Estonia), NE Estonia and the outskirts of Tallinn (Tallinn), fig. 2.

$\mathrm{Cr}$ - Since 1989, the concentrations of $\mathrm{Cr}$ found in mosses in Estonia have decreased by up to $92 \%$. In NE Estonia the concentrations have fallen by $59 \%$. In 2005-2008 the concentrations of $\mathrm{Cr}$ in mosses in the Tallinn area were very close to those for the whole of Estonia. The values are not much higher in NE Estonia, fig. 3. 


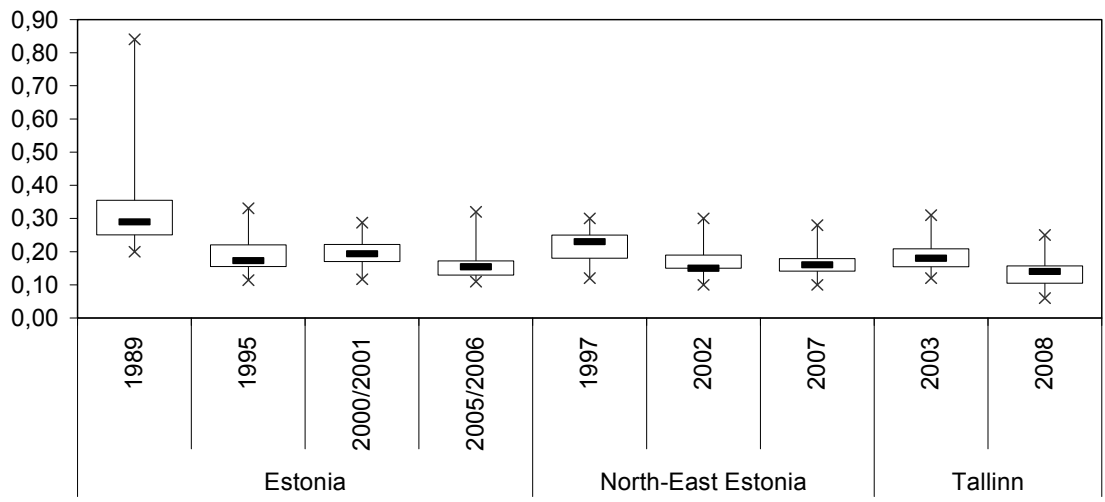

Figure 2: Minimum, maximum and median values, first and third quartile of the concentrations of $\mathrm{Cd}$ in mosses for Estonia (1989, 1995, 2000/2001, 2005/2006), NE Estonia (1997, 2002, 2007) and Tallinn $(2003,2008)$ in $\mu \mathrm{g} / \mathrm{g}$.

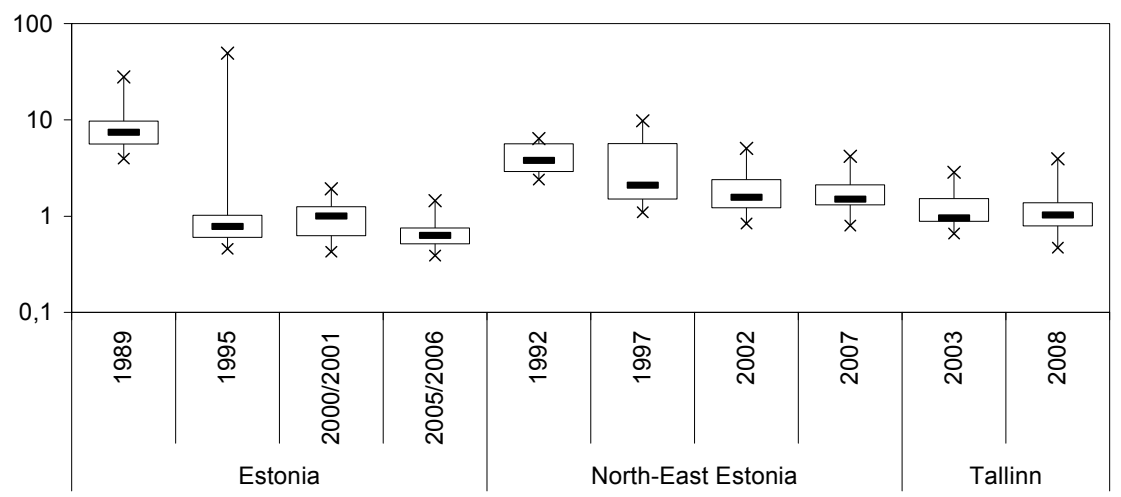

Figure 3: Minimum, maximum and median values, first and third quartile of concentrations of $\mathrm{Cr}$ in mosses for Estonia (1989, 1995, 2000/2001, 2005/2006), NE Estonia (1997, 2002, 2007) and Tallinn (2003, 2008) in $\mu \mathrm{g} / \mathrm{g}$.

$\mathrm{Cu}$ - In the regions with relatively high heavy metal deposition rates such as NE Estonia and the surroundings of Tallinn, the concentrations of $\mathrm{Cu}$ in mosses are almost identical and only show a slightly decreasing trend when the whole country is considered, fig. 4.

$\mathrm{Fe}$ - The concentrations of $\mathrm{Fe}$ in Estonian mosses have decreased by up to $70 \%$ during the last 15 years. The concentrations of Fe in mosses in NE Estonia and Tallinn are more than 2 times higher than the Estonian average, fig. 5. 


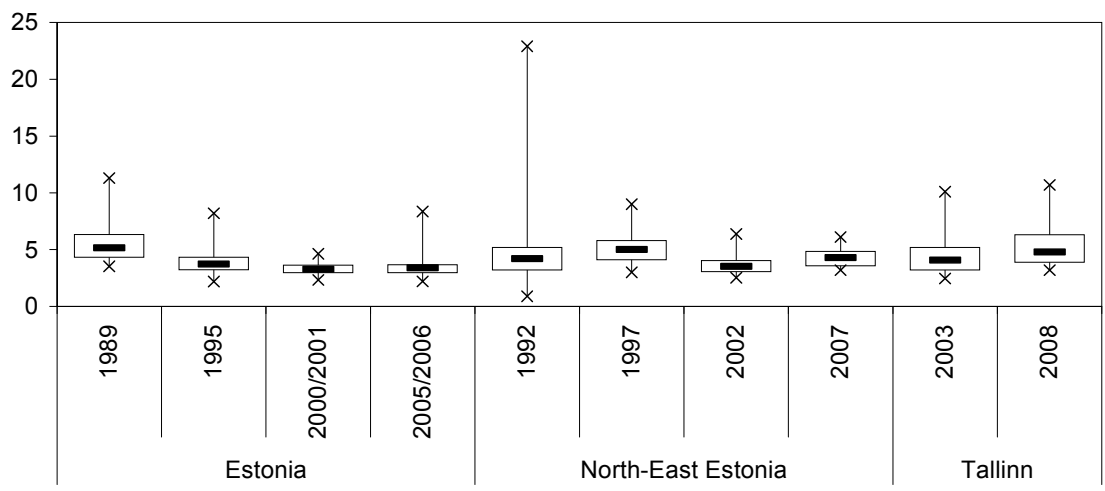

Figure 4: Minimum, maximum and median values, first and third quartile of the concentrations of $\mathrm{Cu}$ in mosses for Estonia (1989, 1995, 2000/2001, 2005/2006), NE Estonia (1997, 2002, 2007) and Tallinn $(2003,2008)$ in $\mu \mathrm{g} / \mathrm{g}$.

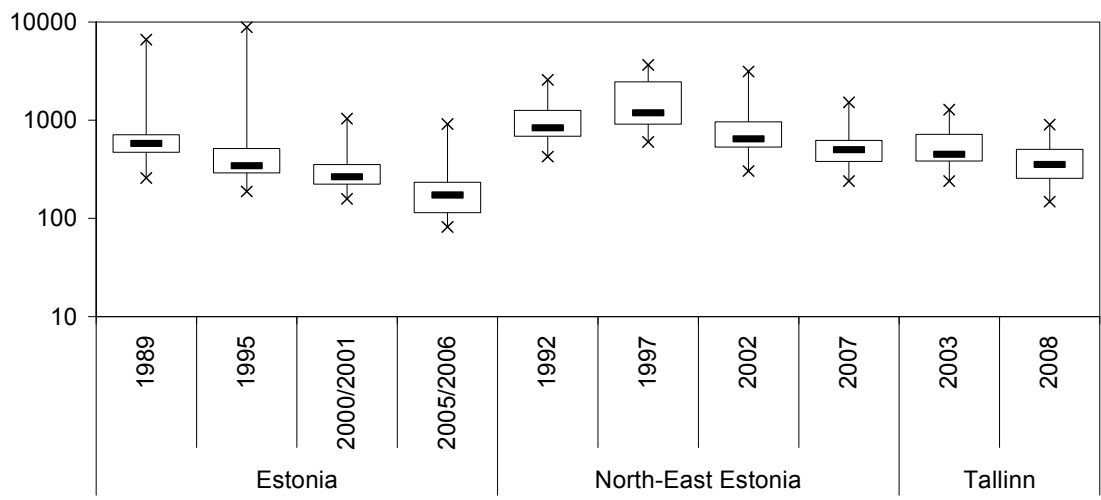

Figure 5: Minimum, maximum and median values, first and third quartile of the concentrations of $\mathrm{Fe}$ in mosses for Estonia (1989, 1995, 2000/2001, 2005/2006), NE Estonia (1997, 2002, 2007) and Tallinn $(2003,2008)$ in $\mu \mathrm{g} / \mathrm{g}$.

$\mathrm{Ni}$ - The concentrations of $\mathrm{Ni}$ in Estonia's mosses have decreased by up to $82 \%$; in NE Estonia the reduction was up to $73 \%$. The concentrations of $\mathrm{Ni}$ in the moss samples collected from NE Estonia in 2007 and from the Tallinn area in 2008 are very similar, and remain only slightly higher than the concentrations for Estonia as a whole measured in 2005/2006, fig. 6 .

$\mathrm{Pb}-\mathrm{The}$ concentrations of $\mathrm{Pb}$ in Estonia's mosses have decreased considerably - by up to $80 \%$ for Estonia as a whole and by $62 \%$ in NE Estonia. The concentrations of $\mathrm{Pb}$ in the moss samples collected from NE Estonia in 2007 are close to the concentrations found in mosses from the Tallinn area in 2008 and higher than those for Estonia in 2005/2006, fig. 7. 


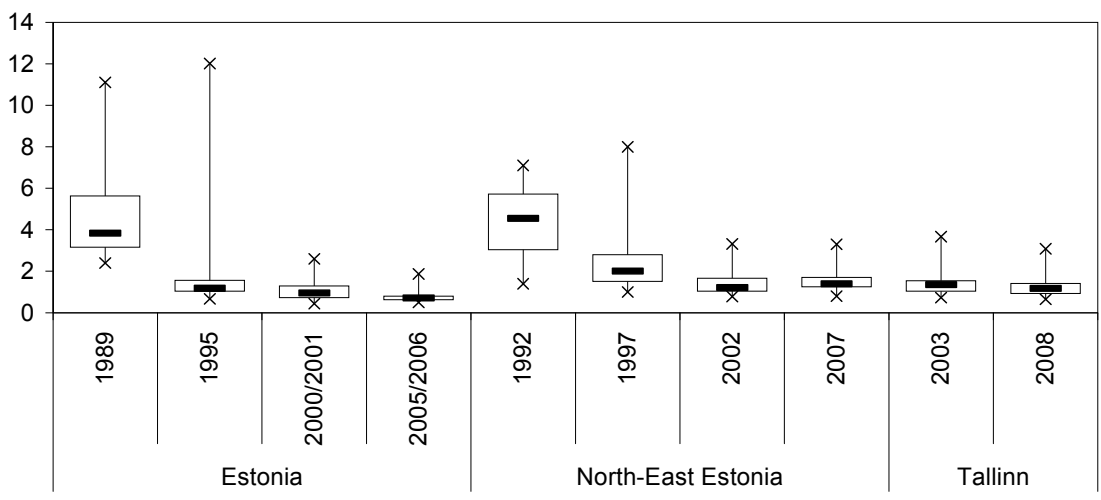

Figure 6: The minimum, maximum and median values, first and third quartile of the concentrations of $\mathrm{Ni}$ in Estonia (1989, 1995, 2000/2001, 2005/2006), NE Estonia (1997, 2002, 2007) and Tallinn (2003, 2008) in $\mu \mathrm{g} / \mathrm{g}$.

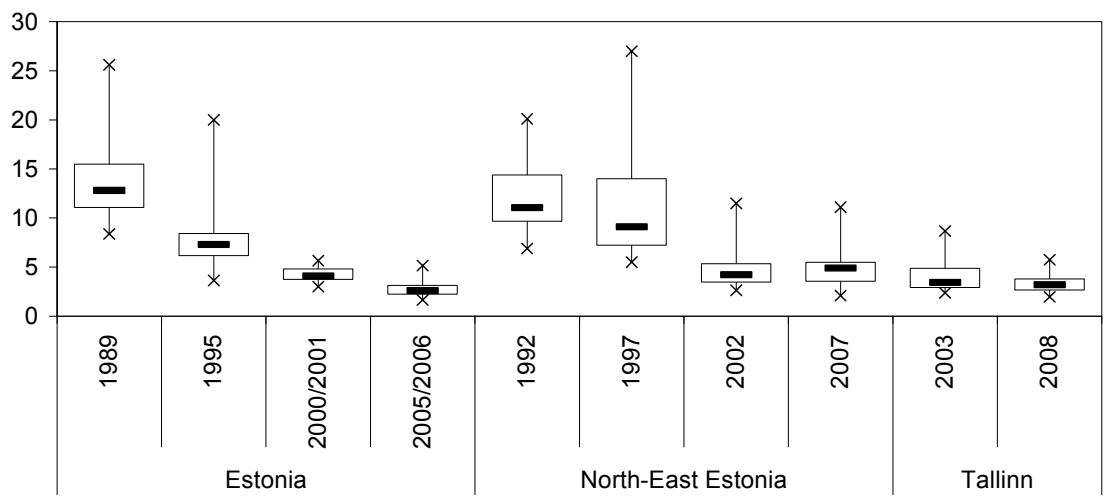

Figure 7: Minimum, maximum and median values, first and third quartile of the concentrations of $\mathrm{Pb}$ in mosses for Estonia (1989, 1995, 2000/2001, 2005/2006), NE Estonia (1997, 2002, 2007) and Tallinn $(2003,2008)$ in $\mu \mathrm{g} / \mathrm{g}$.

$\mathrm{V}$ - The concentrations of $\mathrm{V}$ in the mosses of Estonia have decreased by up to $76 \%$. The concentrations found in NE Estonia in 2007 are very similar to those recorded near Tallinn, but remain higher than in the concentrations for the whole country in 2005/2006, fig. 8 .

$\mathrm{Zn}$ - The concentrations of $\mathrm{Zn}$ in Estonia's mosses do not exhibit a marked shift. The changes remain within the range of local variability. The concentrations of $\mathrm{Zn}$ in the mosses of NE Estonia and Tallinn are nearly identical, fig. 9. 


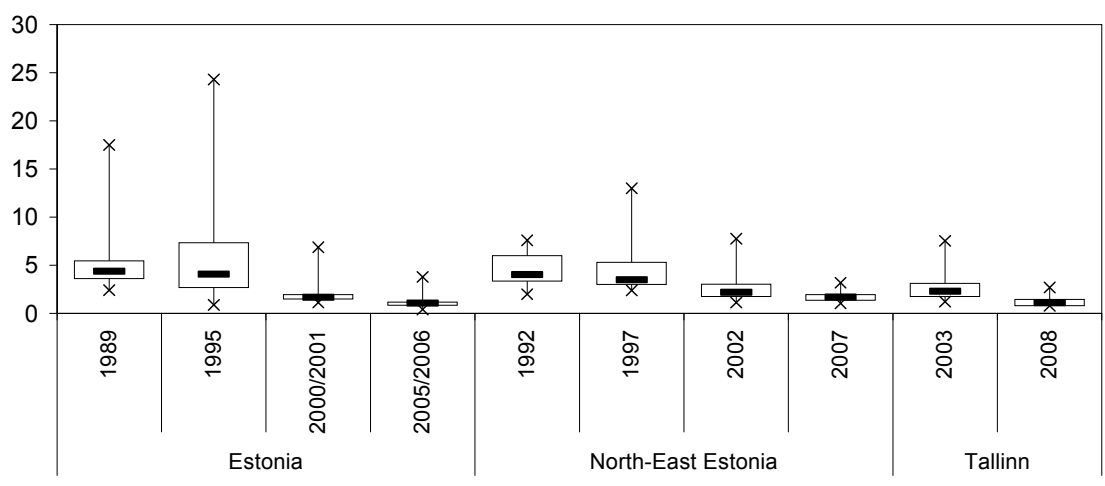

Figure 8: Minimum, maximum and median values, first and third quartiles of the concentrations of $\mathrm{V}$ in mosses for Estonia (1989, 1995, 2000/2001, 2005/2006), NE Estonia (1997, 2002, 2007) and Tallinn $(2003,2008)$ in $\mu \mathrm{g} / \mathrm{g}$.

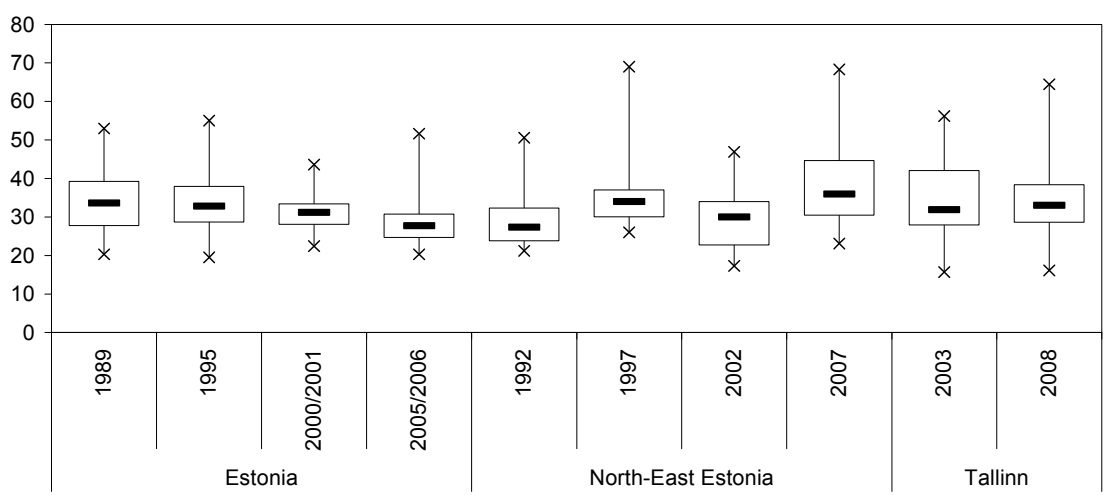

Figure 9: Minimum, maximum and median values, first and third quartile of the concentration of $\mathrm{Zn}$ in mosses for Estonia (1989, 1995, 2000/2001, 2005/2006), NE Estonia (1997, 2002, 2007) and Tallinn $(2003,2008)$ in $\mu \mathrm{g} / \mathrm{g}$.

\section{Discussion}

In 1989, the concentrations of the heavy metals investigated in the study reported here were the highest in moss samples collected from NE Estonia.

By 1995, the surroundings of Tallinn had become the second most polluted area in Estonia, probably due to the impact of increased traffic volumes and the concomitant increase in air pollution.

Traffic pollution consists of brake dust (the product of brake wear), tyre dust and fuel residuals. Fukuzaki et al. [3] showed that tyre dust contains the heavy 
metals $\mathrm{Fe}, \mathrm{Ni}, \mathrm{Cu}, \mathrm{Zn}, \mathrm{Cd}$, and $\mathrm{Pb}$, and contributes to airborne emissions of these elements. $\mathrm{Zn}$ from tyre dust is a significant pollutant in soil, air, street dust, and urban runoff (Smolders and Degryse [28]; Sadiq et al. [29]; Rogge et al. [30]; Fergusson and Kim [31]; Davis et al. [32]). Break dust has been recognized as a significant pollutant for $\mathrm{Cu}$ in the aerosols composition (Sternbeck et al. [5]).

In relation to the drop in power production and the implementation of environmentally friendlier technologies, the emissions of heavy metals from thermal power plants in NE Estonia have fallen remarkably since 1989.

From 1989 to 2008, the decrease in the concentrations of $\mathrm{Cr}, \mathrm{Fe}, \mathrm{Ni}, \mathrm{Pb}$ and $\mathrm{V}$ in Estonian mosses has been in correlation with the decrease of emissions of solid particles from the Balti Power Plant, the Eesti Power Plant and the cement factory of Kunda Nordic Tsement AS (all in NE Estonia).

The concentrations of $\mathrm{Zn}$ (which is a slowly biodegradable element in the environment) have remained almost unchanged during the whole sampling period.

The decrease of concentrations of $\mathrm{Pb}$ in moss samples has been remarkable since 1989. The emission of $\mathrm{Pb}$ has decreased by $80 \%$ during 1990-2008, probably because of the introduction of unleaded fuel in Estonia.

In comparison to the rest of Europe, Estonia belongs to the group of countries with the lowest moss concentration values for $\mathrm{Cr}, \mathrm{Pb}, \mathrm{Fe}, \mathrm{Ni}, \mathrm{V}$ and $\mathrm{Zn}$, and to the group with average concentrations of $\mathrm{Cd}$ and $\mathrm{Zn}$.

The concentrations of heavy metals in Estonia's mosses are similar to those found in moss samples collected from the Nordic countries and from the other Baltic countries.

\section{Summary and conclusions}

The concentrations of $\mathrm{Cd}, \mathrm{Cr}, \mathrm{Cu}, \mathrm{Fe}, \mathrm{Ni}, \mathrm{Pb}, \mathrm{V}$ and $\mathrm{Zn}$ in moss samples have decreased and their spatial distribution has changed since 1989 in Estonia.

The concentrations of $\mathrm{Cd}, \mathrm{Cr}$ and $\mathrm{Ni}$ decreased remarkably from 1989 to 1995, the concentrations of $\mathrm{Pb}$ in 1989-2000/2001 and the concentrations of $\mathrm{V}$ in 1995-2000/2001. The concentrations of Zn during the sampling period have remained within local variability or close to it.

In 1989, the highest concentrations of all heavy metals mentioned above were found in moss samples from NE Estonia. In 1995, moss samples from the region continued to have the country's highest concentrations of $\mathrm{Cd}, \mathrm{Cr}, \mathrm{Fe}, \mathrm{Ni}$ and $\mathrm{V}$, while the concentrations of $\mathrm{Cu}, \mathrm{Pb}$ and $\mathrm{Zn}$ were the highest in the area around Tallinn. In 2000/2001, NE Estonia only accounted for the highest concentrations of $\mathrm{Cu}$ and $\mathrm{Fe}$, the concentrations of $\mathrm{Cr}, \mathrm{Ni}, \mathrm{Pb}, \mathrm{V}$ and $\mathrm{Zn}$ were the highest in the outskirts of Tallinn.

In 2005-2008, the changes of the concentrations of $\mathrm{Cd}, \mathrm{Cr}$, and $\mathrm{Cu}$ in all three regions (Estonia, NE Estonia, Tallinn) remained within local variability or close to it. The concentrations of $\mathrm{Pb}, \mathrm{Ni}$ and $\mathrm{V}$ were slightly higher in moss samples collected from NE Estonia and Tallinn than in samples collected from elsewhere in Estonia. The concentrations of Fe were remarkably higher in NE Estonia than in other regions of the country. 
The emission of solid particles from industrial facilities in NE Estonia has decreased considerably from 1989 to 2008. For instance, the data for the Kunda Nordic Tsement cement plant show a drop that is almost thousandfold. The concentrations of most heavy metals in moss samples across Estonia during the same period demonstrate a remarkable reduction - the concentrations of $\mathrm{Cr}, \mathrm{Fe}$, $\mathrm{Ni}, \mathrm{Pb}$ and $\mathrm{V}$ decreased by $50-80 \%$.

Due to the introduction of unleaded petrol, the concentrations of $\mathrm{Pb}$ in mosses have decreased by up to $60 \%$ during 1989-2008.

\section{References}

[1] Sucharova, J. \& Suchara, I., Biomonitoring of the atmospheric deposition of metals and sulphur compounds using moss analysis in the Czech Republic. Results of International Biomonitoring Programme 1995. Research Institute of Ornamental Gardening Průhonice, Průhonice. 1995.

[2] Callender, E., Heavy metals in the environment - historical trends. Environmental geochemistry, 9, pp. 67-107, 2005.

[3] Fukuzaki, N., Yanaka, T. \& Urushiyama Y., Effects of studded tires on roadside airborne dust pollution in Niigata, Japan. Atmospheric Environment, 20, pp. 377-86, 1986.

[4] Ikeda, M., Zhang, Z.W., Shimbo, S., Watanabe, T., Nakatsuka, H., Moon, C.S., Matsuda-Inoguchi, N. \& Higashikawa, K., Urban population exposure to lead and cadmium in east and south-east Asia. The Science of the Total Environment, 249, pp. 373-384, 2000.

[5] Sternbeck, J., Sjödin, Å. \& Andre'asson, K., Metal emissions from road traffic and the influence of resuspension-results from two tunnel studies. Atmospheric Environment, 36, pp. 4735-44, 2002.

[6] Adachi, K. \& Tainosho, Y., Characterization of heavy metal particles embedded in tire dust. Environment International, 30, pp. 1009- 1017, 2004.

[7] Harmens, H., Norris, D.A., Steinnes, E., Kubin, E., Piispanen, J., Alber, R., Aleksiayenak,Y., Blum, O., Coşkun, M., Damh, M., De Temmerman, L., Fernández, J.A., Frolova, M., Frontasyeva, M., González- Miqueom, L., Grodzińska, N., Jeran, Z., Korzekwa, S., Krmar, M., Kvietkus, K., Leblond, S., Liiv, S., Magnússon, S.H., Maňkovská, B., Pesch, R., Rühling, Å., Santamariam, J.M., Schröder, W., Spiric, Z., Suchara, I., Thöni, L., Urumov, V., Yurukova, L. \& Zechmeister, H.G., Mosses as biomonitors of atmospheric heavy metal deposition: Spatial patterns and temporal trends in Europe. Environmental Pollution, 158, pp. 3144-3156, 2010.

[8] Liiv, S. \& Kaasik, M., Spatial and temporal variability of trace metals in mosses in Estonia. Forestry Studies/Metsanduslikud Uurimused, 46, pp. 35-44, 2007.

[9] Punning, J.M. \& Raukas, A., Environmental problems in the Estonian oil shale industry. Energy and Environmental Science, 2, pp. 723-728, 2009. 
[10] Raukas, A., Opening a new decade. Oil Shale, A Scientific-Technical Journal, 21(1), pp. 1-2, 2004.

[11] Walkenhorst, A., Hagemeyer, J. \& Breckle, W.S., Passive Monitoring of Airborne Pollutants, Particularly Trace Metals, with Tree Bark. Plants as Biomonitors. Indicators for Heavy Metals in the Terrestrial Environment, ed B. Markert, VCH, Weinheim, pp. 523-540, 1993.

[12] Ferner, D.J., Toxicity, heavy metals. eMed Journal, May 25, 2(5), pp. 1, 2001.

[13] Ma, H.W., Hung, M.L. \& Chen, P. C., A systemic health risk assessment for the chromium cycle in Taiwan. Environment International, 10, pp. 1016, 2006.

[14] Rühling, Å. \& Tyler, G., An ecological approach to the lead problem. Botaniska Notiser, 122, pp. 248-342, 1968.

[15] Holy, M., Pesch, R., Schröder, W., Harmens, H., Ilyin, I., Alber, R., Aleksiayenak, Y., Blum, O., Coşkun, M., Dam, M., De Temmerman, L., Fedorets, N., Figueira, R., Frolova, M., Frontasyeva, M., Goltsova, N., Gonzalez Miqueo, L., Grodzińska, K., Jeran, Z., Korzekwa, S., Krmar, M., Kubin, E., Kvietkus, K., Larsen, M., Leblond, S., Liiv, S., Magnússon, S., Maňkovská, B., Mocanu, R., Piispanen, J., Rühling, Å., Santamaria, J., Steinnes, E., Suchara, I., Thöni, L., Turcsányi, G., Urumov, V., Wolterbeek, B., Yurukova, L., \& Zechmeister, H.G., First thorough identification of factors associated with $\mathrm{Cd}, \mathrm{Hg}$ and $\mathrm{Pb}$ concentrations in mosses sampled in the European Surveys 1990, 1995, 2000 and 2005. Journal of Atmospheric Chemistry, 63, pp. 109-124, 2009.

[16] Brown, D.H., Mineral nutrition. Bryophyte Ecology, ed. A.J.E. Smith, Chapman and Hall: London, pp. 383-444, 1982.

[17] Brown, D. H., \& Brumelis, G., A biomonitoring method using the cellular distribution of metals in moss. The Science of the Total Environment, 187, pp. 153-161, 1996.

[18] Tyler, G., Bryophytes and heavy metals. A literature review. Botanical Journal of the Linnean Society, 104, pp. 231-253, 1990.

[19] Sawidis, T., Zachariadis, G., Stratis, J. \& Ladoukakis, E., Mosses as Biological Indicators for Monitoring of Heavy Metal Pollution. Fresenius Environmental Bulletin, 2, pp. 193-199, 1993.

[20] Thöni, L., Schnyder, N. \& Krieg, F., Comparison of metal concentrations of three species of mosses and metal freights in bulk precipitation. Fresenius Journal of Analytical Chemistry, 354, pp. 703-708, 1996.

[21] Markert, B., Wappelhorst, O., Weckert, V., Herpin, U., Siewers, U., Friese, K. \& Breulmann, G., The use of bioindicators for monitoring the heavymetal status of the environment. Journal of Radioanalytical and Nuclear Chemistry, 240(2), pp. 425-429, 1999.

[22] Fernandez, J. A., Ederra, A., Nunez, E., Martinez-Abaigar, J., Infante, M., Heras, P., Elias, M. J., Mazimpaka, V. \& Carballeira, A., Biomonitoring of metal deposition in northern Spain by moss analysis. The Science of the Total Environment, 300, pp. 115-127, 2002. 
[23] Rühling, A., Brumelis, G., Goltsova, N., Kvietkus, K., Kubin, E., Liiv, S., Magnusson, S., Mäkinen, A., Pilegaard, K., Rasmussen, L., Sander, E. \& Steinnes, E., Atmospheric Heavy Metal Deposition in Northern Europe in 1990. NORD, 12, 41 pp, 1992.

[24] Mäkinen, A., Biomonitoring of atmospheric heavy metal deposition in Estonia: A chemical survey of mosses in 1989, Report no. 1/93, Ministry of Environment of Finland, 1994

[25] Liiv, S. \& Kaasik, M., Trace metals in mosses in the Estonian oil shale processing region. Journal of Atmospheric Chemistry, 49, pp. 563-578. 2004.

[26] Rühling, Å., Rasmussen, L., Pilegaard, K., Mäkinen, A. \& Steinnes, E., Survey of Atmospheric Heavy Metal Deposition in the Nordic countries in 1985 - monitored by moss analyses. Nord, 21. 44 pp, 1987.

[27] Atmospheric Heavy Metal Deposition in Europe 1995-1996. Nord, 15, 66 pp, 1998.

[28] Smolders, E. \& Degryse, F., Fate and effect of zinc from tire debris in soil. Environmental Science and Technology, 36, pp. 3706-10, 2002.

[29] Sadiq, M., Alam, I., El-Mubarek, A.m \& Al-Mohdhar, H.M., Preliminary evaluation of metal pollution from wear of auto tires. Bulletin of Environmental Contamination and Toxicology, 42, pp. 743-8, 1989.

[30] Rogge, W.F., Hildemann, L.M., Mazurek, M.A., Cass, G.R. \& Simoneit B.R., Sources of fine organic aerosol: 3. Road dust, tire debris, and organometallic brake lining dust: roads as sources and sinks. Environmental Science and Technology, 27, pp. 1892-904, 1993.

[31] Fergusson, J.E. \& Kim, N.D., Trace elements in street and house dusts: sources and speciation. The Science of the Total Environment, 100, pp. 125- 50, 1991.

[32] Davis, A.P., Shokouhian, M. \& Ni, S., Loading estimates of lead, copper, cadmium, and zinc in urban runoff from specific sources. Chemosphere, 44 , pp. 997-1009, 2001. 